\title{
An Efficient and Solvent Free Synthesis of N-Aryl 2,3-Dihydro-4H naphtho-[2,1-e] 1,3-oxazines
}

\author{
Mohammad S Al-Ajely* and Ahmed M Noori \\ Department of Chemistry, College of Education for girls, Mosul University, Mosul, Iraq
}

*Corresponding author: Mohammad S Al Ajely, Department of Chemistry, College of Education for girls, Mosul University, Mosul, Iraq

\section{ARTICLE INFO}

Received: 蔧 August 03, 2020

Published: August 13, 2020

Citation: Mohammad S Al-Ajely, Ahmed M Noori. An Efficient and Solvent Free Synthesis of N-Aryl 2,3-Dihydro-4H naphtho-[2,1-e] 1,3-oxazines. Biomed J Sci \& Tech Res 29(3)-2020. BJSTR. MS.ID.004815.
ABSTRACT

Oxazine compounds have proved to have many pharmaceutical applications and most of these compounds now a days are used as drugs. For the importance of this class of heterocyclic compounds we are here investigate the synthesis of new derivatives of 1,3-oxazines using solvent free one pot three component system in a drug discovery program ,so starting from $\beta$-Naphthol, formaldehyde and aromatic amines in presence of zarconyl chloride as catalyst. compounds 1-9 were synthesized, Benzo 1,3 diazines (1014) were also synthesized from their corresponding 1,3 oxazines. These compounds were characterized by IR, some representative by [1] HNMR and were discussed.

Keywords: Aryl; 1,3-Naphthoxazines; Solvent free; synthesis

\section{Introduction}

Due to their importance in biological applications oxazines have drew attention of many researchers to investigate this type of hetrocyclic compounds. these researchers have succeeded to prepare different types of oxazines using different methodologies [1-10] most of the starting material is anthranilic acid or its derivatives with aldehydes, isocyanate, acetic anhydride or with oxazolones [11]. Some other researchers used phenal, amine and aldehydes to the synthesis of these oxazine compounds [12]. Other researchers used chalcones for the synthesis of this type of compounds $[13,14]$ or from 2-Iodoaryl Azides and Amines [15]. Among the studied reactions of oxazine compounds were opening and reclosing of the oxazine ring which is the other way for the synthesis of new oxazine derivatives [16]. The research work on studying the biological activities of some oxazine compounds revealed that most of these compounds have several pharmacological applications for using

\section{General Procedure for the Synthesis of Naphthaoxazine Copmounds (1-9)}

Table 1: Physical properties of compounds (1-9).

\begin{tabular}{|c|c|c|c|c|c|}
\hline Comp. No. & Ar & Molecular formula & M.wt & m.p. $\left({ }^{\circ} \mathrm{C}\right)$ & Yield (\%) \\
\hline 1 & 4-chlorophen & & 295.76 & $98-100$ \\
\hline
\end{tabular}

these compounds as drugs [17-19]. In addition the latest studies on oxazine compounds showed the ability to stop the cancer cell growth and repairing the DNA strands [20] and according to the above facts we studied the synthesis of some new compounds using green technique for this synthesis. These new compounds will be our goal for studying their biological activities in our ongoing drug discovery program.

\section{Experimental}

All melting points were uncorrected using electro thermal SMP30 UK melting point apparatus. IR spectra were recorded using Alpha (ATR) instrument. [1] HNMR spectra were recorded using Varian Agilant (USA) $300 \mathrm{MHz}$ instrument, DMSO as solvent. All chemical was supplied by sigma -Aldrich, BDH and Fluka companies. Compounds $10 \mathrm{a}$, b was synthesized following some published procedure [21] 


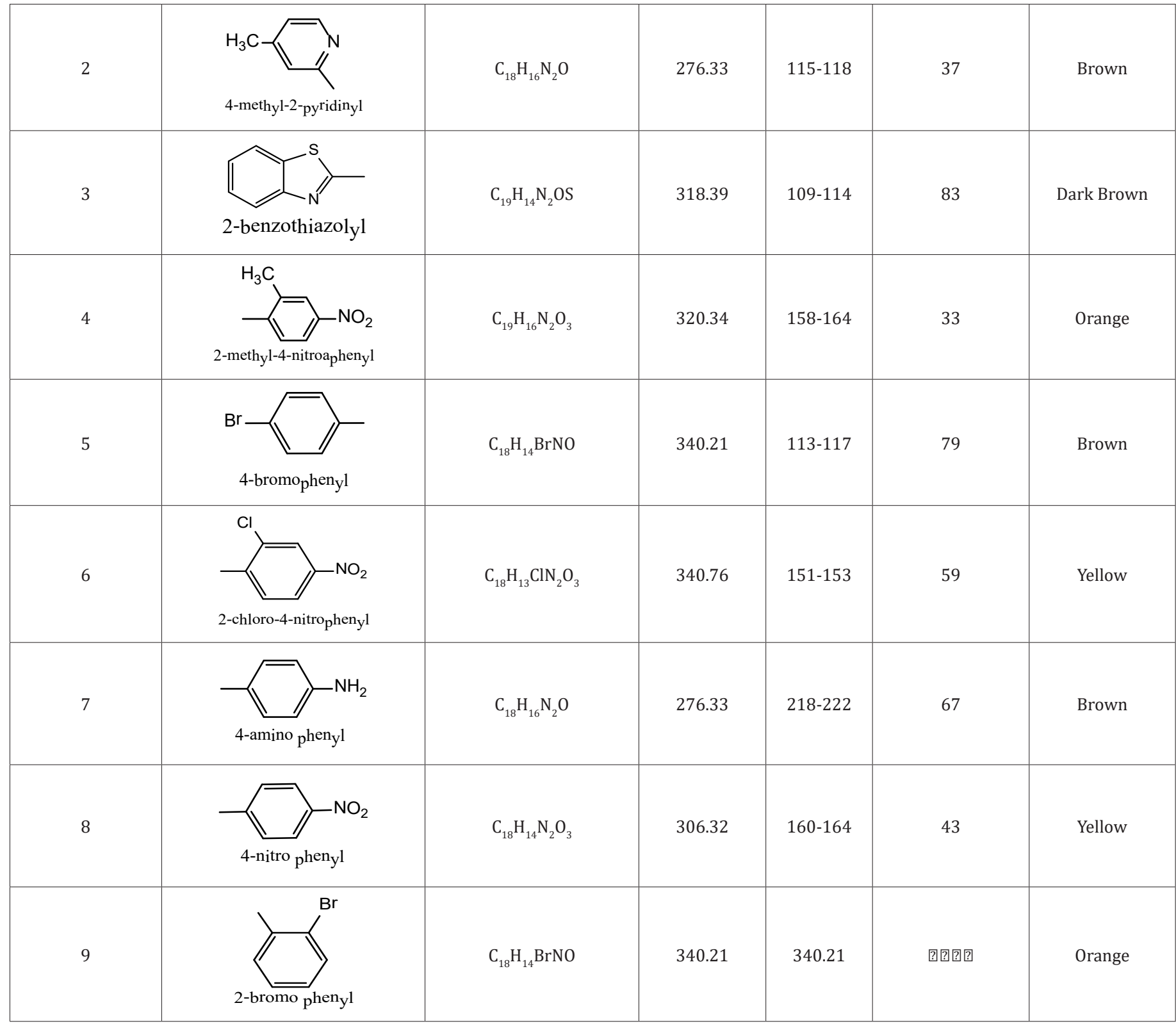

Formaldehyde $\left(0.2 \mathrm{~mol}\right.$ ), Zarconyl chloride (ZrOCL2,8H $\mathrm{H}_{2} \mathrm{O}$ (0.2mol.),2-naphthol ( $0.1 \mathrm{~mol}$.) and aromatic amine (0.1 mol.). This mixture was grinding by porcelain mortar for $30 \mathrm{~min}$, after that dichloromethane $\left(\mathrm{CH}_{2} \mathrm{CL}_{2}\right)$ was then added. The organic layer was then separated and washed twice with brine then with water. The organic layer was separated. Evaporation of the solvent by rotary evaporator afforded a crude product which was recrystallized from minimum amount of methanol. Physical properties were listed in the following Table 1.

Table 2: Physical properties of compounds (10-13).

\begin{tabular}{|c|c|c|c|c|c|c|}
\hline Comp. o. & Ar & Molecular formula & M.wt & m.p. $\left({ }^{\circ} \mathrm{C}\right)$ & Yield (\%) & Colour \\
\hline 10 & & $\mathrm{C}_{21} \mathrm{H}_{17} \mathrm{NO}$ & 299.37 & $86-92$ & 83 & brown \\
\hline 11 & nzothii & $\mathrm{C}_{18} \mathrm{H}_{14} \mathrm{~N}_{2} \mathrm{OS}$ & 306.38 & 193-196 & 92 & white \\
\hline
\end{tabular}

\section{General Procedure for the Preparation of N-Substituted 2-Methyl, Aryl Benzo-1,3-Diazine-4-one (11-24)}

compound $10 \mathrm{a}$ or $10 \mathrm{~b}(0.1 \mathrm{~mol})$, aromatic or aliphatic amine $(0.1 \mathrm{~mol})$, This mixture was refluxed for $6 \mathrm{~h}$, cooled. The whole mixture was then powered on cold water $(50 \mathrm{ml})$ with stirring. The precipitate was filtered off and dried then crystallized from benzene. The physical properties for the synthesized compound were illustrated in Table 2 (Schem 1,2). 


\begin{tabular}{|l|l|l|l|l|l|}
\hline 12 & $\mathrm{C}_{14} \mathrm{H}_{12} \mathrm{~N}_{2} \mathrm{OS}$ & 256.32 & $171-173$ & 89 \\
\hline 13 & $\mathrm{C}_{17} \mathrm{H}_{16} \mathrm{~N}_{2} \mathrm{O}$ & 264.32 & $154-157$ & 90 \\
\hline
\end{tabular}
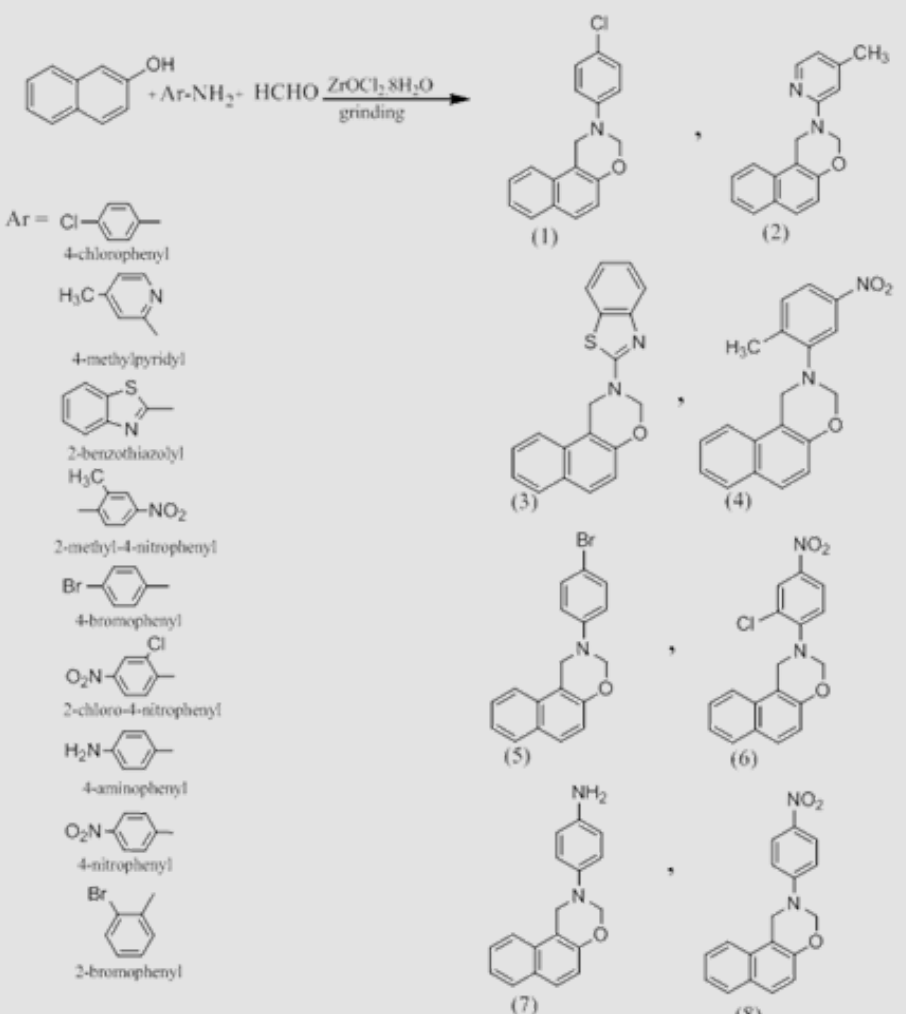

(8)

schem (1)

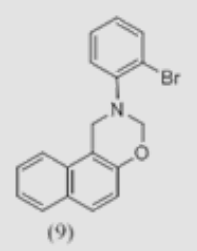

Scheme 1.

\section{Results and Discussion}

It is worth to state here that power sonic 405 micro processes -controlled bench-top ultra-sonic cleaner was used for ultrasonic chemical condensation affording nearly the same yield within the same given time which is another green technique for the synthesis of these compounds.As it was mentioned in the experimental part .compounds 10 a,b were prepared and showed the same melting points, for $10 \mathrm{a}$ was found; $79-81$ published: $81-82^{\circ} \mathrm{C}$, while for $10 \mathrm{~b}$ it was found $120^{\circ} \mathrm{C}$ the published one at $121-122^{\circ} \mathrm{C}$ with identical IR data [21].

\section{N-Aryl 2,4H(1,2E) (1,3) Napha Oxazine Compounds (1-9)}

These compounds were synthesized using similar procedure
[22] and were characterized by IR and showed the following main absorption bands $\left(\mathrm{U}_{\max } \mathrm{cm}^{-1}\right)$ :3020-3092 for $\mathrm{CH}$, sharp bands at (1654- 1624) for $\mathrm{C}=\mathrm{N}, 1589-1454$ for $\mathrm{C}=\mathrm{C}, \mathrm{C}=\mathrm{c}$ Aromatic . While $\mathrm{C}=\mathrm{N}$ appeare at $1390-1328, \mathrm{C}-\mathrm{O}-\mathrm{C}$ at $1250-1022$ other band were illustrated in Table 3. [1] HNMR for individual compounds were as follow:

\section{Compound (1)}

In which the aryl group is p-Chloro phenyl. The Aromatic protons were 6 types as follows :7.99, 7.83, 7.7.81ppm. for carbon 8 of naphthyl ring, 7.71, 7.7ppm. for proton 5 . this ring $7.54,7.40 \mathrm{ppm}$ for protons 6,7 while protons 4,3 appeared at 7.12, 7.11 and 7.054, 7.02ppm. Phenyl protons appeared as $A B(q)$ at, 6.79, 6.78 ppm. 
$\mathrm{CH}_{2}$ protons of the oxazine ring between oxygen and nitrogen ap- $\quad 4.77 \mathrm{ppm}$. protons of naphthyl ring protons appeared as two triplet peared at 5.54, 5.5ppm. and the other $\mathrm{CH}_{2}$ protons appeared at 4.96, signals which can be easily differentiated from other protons.

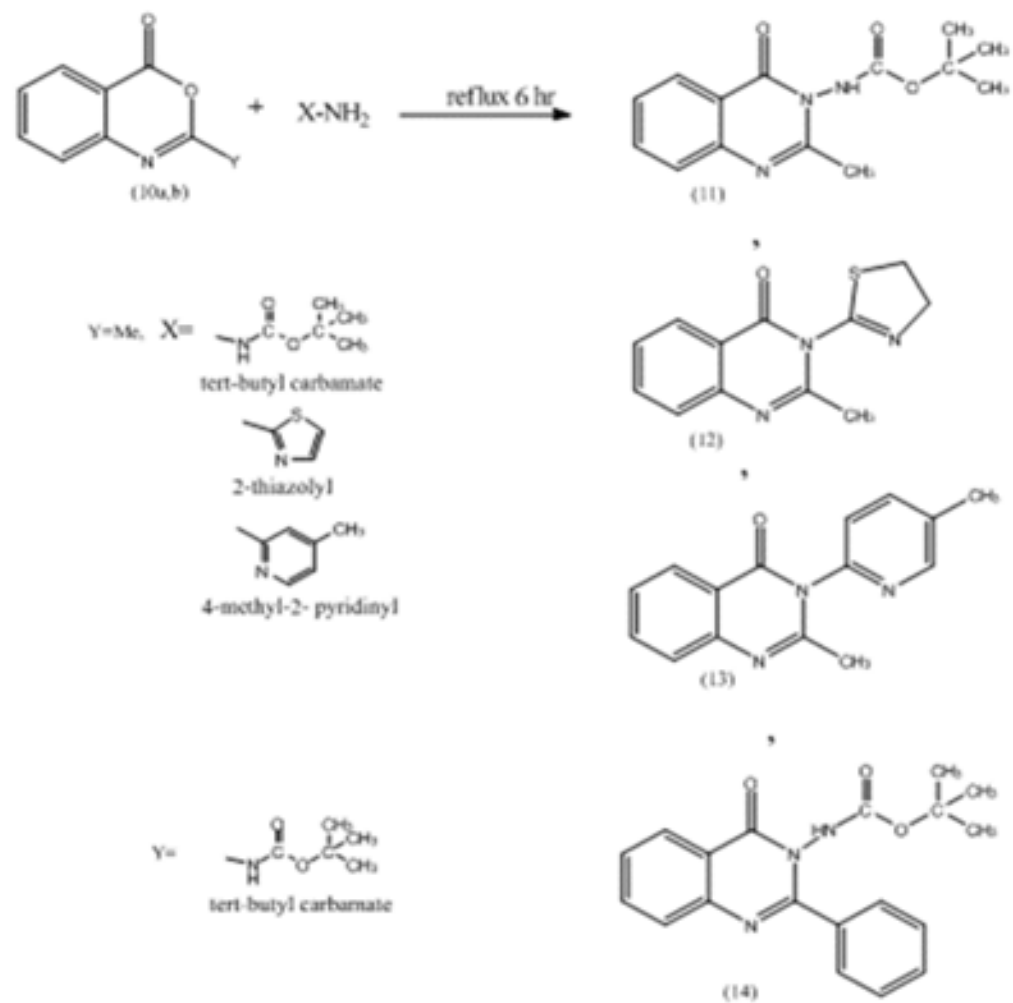

Scheme 2.

Table 3: Physical properties of compounds (10-13).

\begin{tabular}{|c|c|c|c|c|c|c|c|}
\hline \multirow{2}{*}{ Comp. No. } & \multirow{2}{*}{ Ar } & \multicolumn{6}{|c|}{ IR $v \mathrm{~cm}^{-1}$ (neet) } \\
\hline & & Ar C-H & $\mathrm{C}=\mathrm{N}$ & $\mathrm{C}=\mathrm{-C}$ ArC $=\mathrm{C}$, & C-N & C-O-C & Others \\
\hline 1 & $\underbrace{}_{\text {4-chlorophen }}$ & 3059 & ----- & 1588,1482 & 1366 & 1220,1094 & $\begin{array}{l}\mathrm{C}-\mathrm{Cl} \\
736\end{array}$ \\
\hline 2 & 4-methyl-2-pyridinyl & 3048 & 1628 & $\begin{array}{c}1586 \\
1505,1454\end{array}$ & 1328 & 1204,1157 & $\begin{array}{c}\text { C-H alph } \\
2910\end{array}$ \\
\hline 3 & 2-benzothiazolyl & 3020 & 1654 & 1572,1462 & 1381 & 1256,1066 & $\begin{array}{l}\text { C-S } \\
749\end{array}$ \\
\hline 4 & 2-methyl-4-nitroaphenyl & 3051 & ----- & $\begin{array}{c}1588 \\
1508,1464\end{array}$ & 1390 & 1215,1046 & $\begin{array}{c}\mathrm{N}-\mathrm{O} \\
\text { sym1259 } \\
\text { asym1508 }\end{array}$ \\
\hline 5 & 4-bromophenyl & 3061 & ----- & $\begin{array}{c}1586 \\
1551,1478\end{array}$ & 1368 & 1219,1064 & $\begin{array}{l}\mathrm{C}-\mathrm{Br} \\
486\end{array}$ \\
\hline
\end{tabular}




\begin{tabular}{|c|c|c|c|c|c|c|c|}
\hline 6 & 2-chloro-4-nitrophen ${ }_{\mathrm{yl}}$ & 3092 & ----- & $\begin{array}{c}1587 \\
1503,1461\end{array}$ & 1329 & 1225,1022 & $\begin{array}{c}\mathrm{N}-\mathrm{O} \\
\text { sym1273 } \\
\text { asym1503 }\end{array}$ \\
\hline 7 & $\underbrace{}_{\text {4-amino }} \mathrm{Nhen}_{\mathrm{yl}}$ & 3054 & ---- & $\begin{array}{c}1549 \\
1510,1468\end{array}$ & 1375 & 1222,1059 & $\begin{array}{l}\mathrm{N}-\mathrm{H}_{2} \\
3278 \\
3364 \\
\end{array}$ \\
\hline 8 & $\underbrace{}_{4-\text { nitro phen }} \mathrm{l}$ & 3063 & ---- & $\begin{array}{c}1589 \\
1502,1481\end{array}$ & 1323 & 1235,1060 & $\begin{array}{c}\text { NO- } \\
\text { sym1268 } \\
\text { asym1589 }\end{array}$ \\
\hline
\end{tabular}

\section{Compound (2), Ar is (4-methyl-2-pyridyl)}

This compound also showed 6 signals for the aromatic protons resonated at 8.1, 8.0, 7.5, 7.4, 6.85ppm, for 8,5,6, 7,3,4 protons while the phenyl protons appeared at 7.9, $7.89 \mathrm{ppm}$. for AB like system, $7.53,7.52 \mathrm{ppm}$. for the rest protons nearly equivalents oxazine protons, $\mathrm{CH} 2$ resonated at $5.7,5.68 \mathrm{ppm}$. for protons 4,3 respectively.

\section{Compound (6) Ar is (2-Bromo phenyl)}

Protons NMR chart for this compound also showed the following signals: 8.0, 8.02, 7.5, 7.45, 7.65, 6.91 ppm. for naphthyl ring protons of 8,5 protons, 6,7 and 3,4 protons respectively for oxazine ring protons $6.1,5.05 \mathrm{ppm}$ while the phenyl ring protons 7.61 ortho to carbon bearing Br substituent, 6.67, 7.21, 6.65ppm. for the next protons the value of $6.65 \mathrm{ppm}$. is for proton of the ring adjacent to the nitrogen attachment.

\section{Compound (8) where Ar is (p-Amino phenyl)}

This compound showed the following resonating signals :8.1, $8.02,7.54,7.4,7.64,6.9 \mathrm{ppm}$. for 8,5,6,7 and 4,3 protons respectively. Oxazine protons showed two signals (with and opposite side of ring plane) at 6.1, $6.05 \mathrm{ppm}$. for $\mathrm{CH}_{2}$ between $\mathrm{N}, \mathrm{O}$ atoms and near Table 4: IR data for compounds (11-14).
$\mathrm{N}$ atom respectively. The phenyl protons appeared as two types of protons; near nitrogen oxazine attachment at 6.1, 6.05ppm, near $\mathrm{NH}^{2}$ on both sides $6.45,6.46 \mathrm{ppm}$. while the phenyl $\mathrm{NH}_{2}$ protons resonated at 5.5 .

\section{Compound (9) where Ar is (o-methyl, P-Nitro phenyl)}

This compound was also giving 3 types of protons of the NMR spectra of naphthyl ring protons resonating at 8.1, 8.02, 7.54, 7.41, $7.65,6.91 \mathrm{ppm}$. for $8,7,6,5$ and 3,4 protons. The oxazine ring protons were resonating at $5.0,6 \mathrm{ppm}$. for $\mathrm{CH}_{2}$ near $\mathrm{N}$ atom and between $\mathrm{N}$, $\mathrm{O}$ atoms respectively. Phenyl ring protons of two types resonating at 7.89, 7.87ppm. near $\mathrm{NO}_{2}$ group, 6.0ppm. near nitrogen attachment of the oxazine ring, $\mathrm{CH}_{2}$ of oxazine near nitrogen $5.0 \mathrm{ppm}, 6.1 \mathrm{ppm}$. for the $\mathrm{CH}_{2}$ protons of the oxazine between $\mathrm{N}, \mathrm{O}$ atoms while the protons of the phenyl ring appeared at $2.1 \mathrm{ppm}$.

\section{N-substituted, Methyl or Phenyl Benzoxazine -4- one Compounds (11-14)}

The detail of IR data for these compounds were shown in Table 4. The NMR spectra of some selected samples were characterized by the following resonating signals:

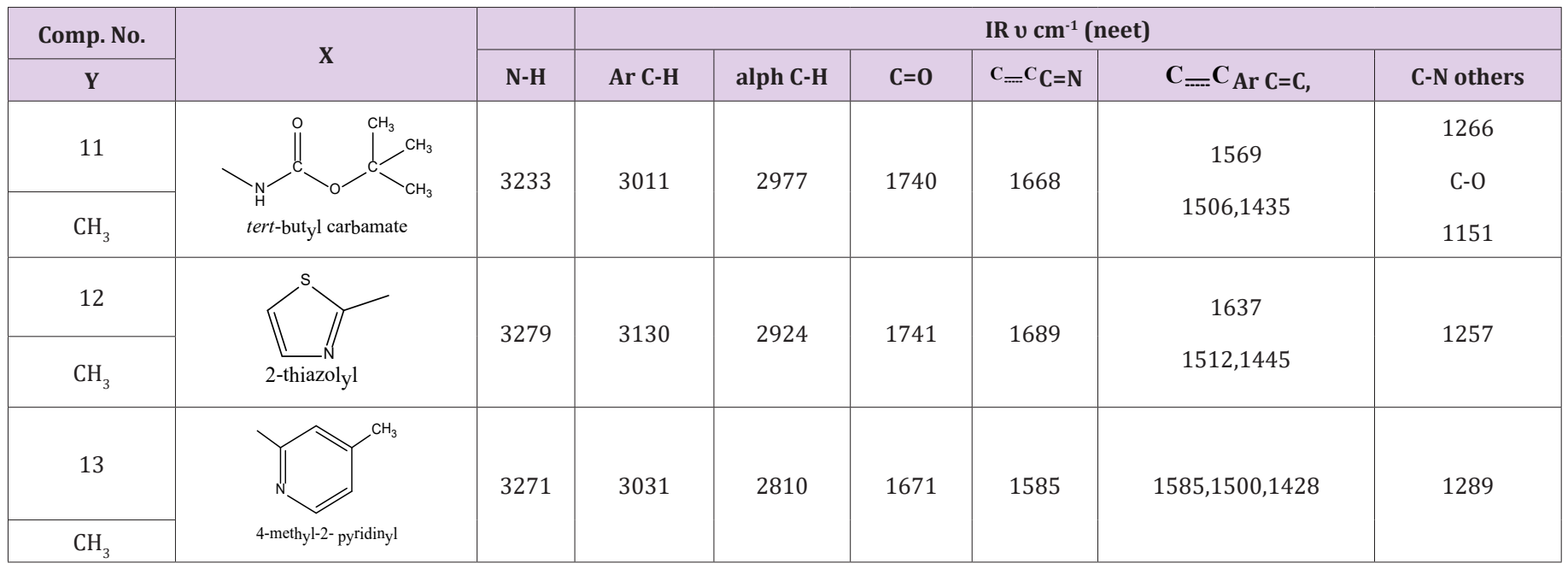




\begin{tabular}{|c|c|c|c|c|c|c|c|c|}
\hline 14 & $\|$ & 3326 & 3067 & 2977 & 1742 & 1639 & 159015071436 & 1233 C-0 \\
\hline$-\mathrm{Ph}$ & tert-butyl carbamate & & & & & & & 1153 \\
\hline
\end{tabular}

Compound (11) 2-mrthyl -N-t-butyl -4-oxo benzo -1,3 - Diazino Carbamate

The benzene ring protons were found at 8.12 , ppm. for carbon 5 proton, 7.65 , for carbon 8 proton. The other protons of this ring were resonated at 7.86, 7.65, 7.61ppm for protons at carbon,7,6 respectively, protons of the t-Butyl group appeared at $1.48 \mathrm{ppm}, 3.16$ ppm for $\mathrm{CH}_{3} \mathrm{NH}$ at $10 \mathrm{ppm}$.

\section{Compound (12) N-2thiozolyl-4 benzo-1,3-Diazine-4-one}

Benzene ring protons appeared at 8.4, 8.0, 7.62ppm assigned to protons $2,5,8$ and at 7.7, 7.6ppm. for protons 7,6 respectively. The thiozolyl protons appeared at 7.2 (near nitrogen proton), the other at $6.7 \mathrm{ppm}, 3.18 \mathrm{ppm}$. for $\mathrm{CH}_{3}$ of Diazine ring protons and 2.35ppm. for pyridyl protons (Figures 1,2).

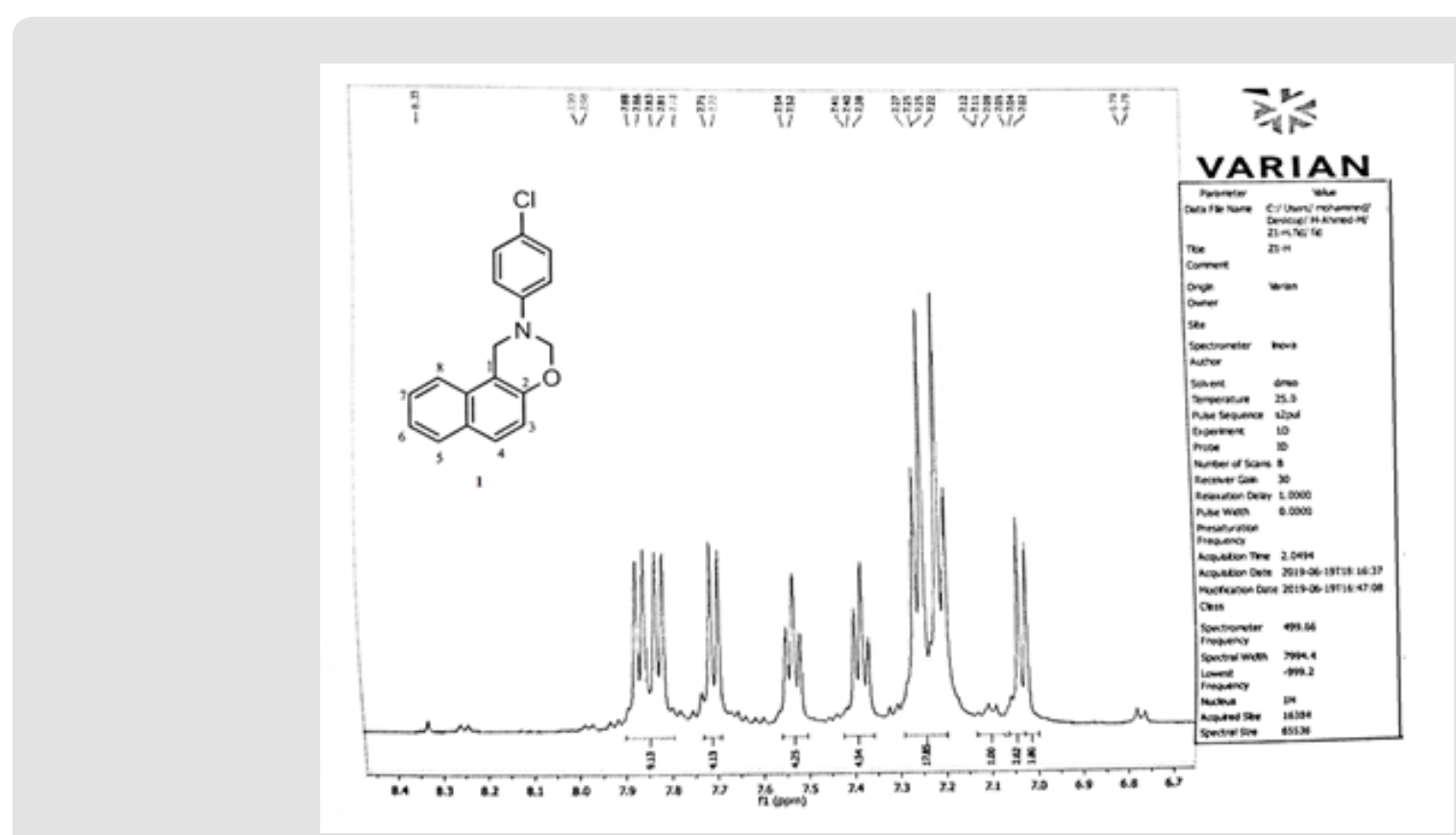

Figure 1.

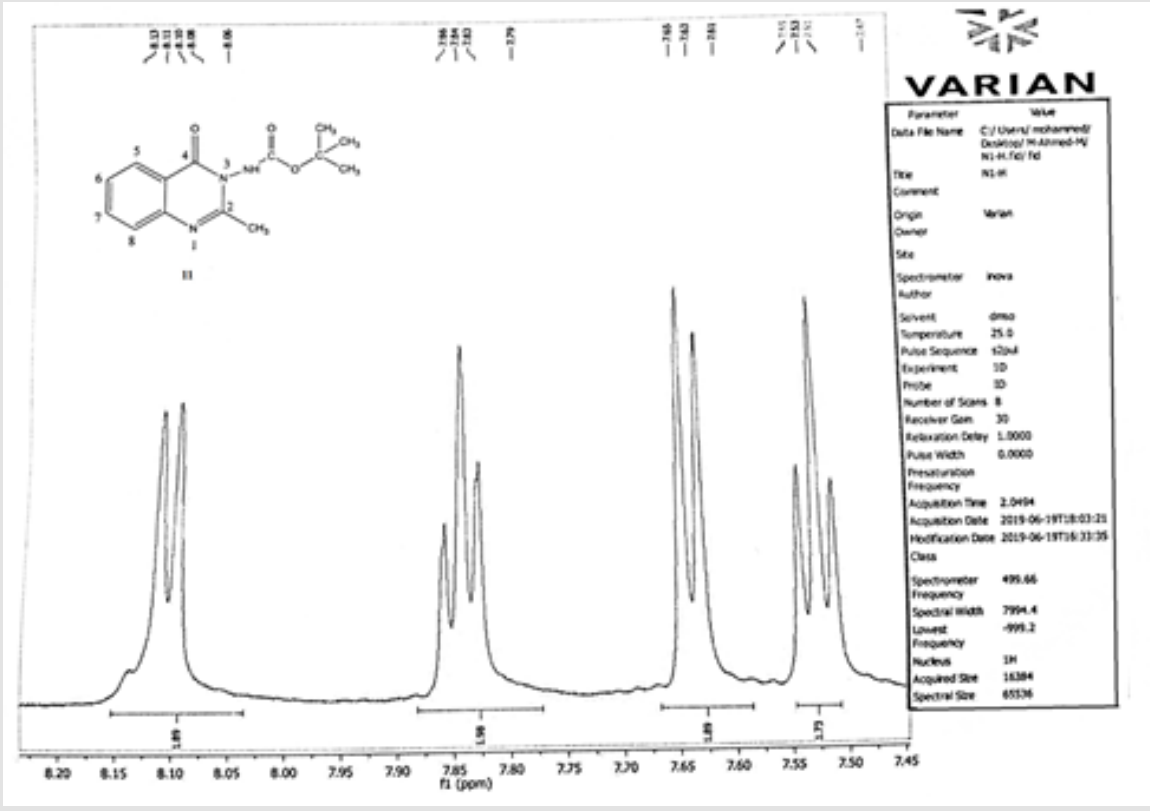

Figure 2. 


\section{Conclusions}

We conclude from the above study that all the synthesized compounds were a really oxazine compounds that is comes from their structure's elucidation using the spectral data for both green techniques used on their synthesis. The screening effects will be studded and their results will be our next paper.

\section{Acknowledgment}

We greatly acknowledge the Iraqi Ministry of higher Education for providing Ahmed M. Noori a scholarship to perform this work which is part of his MSc Thesis.

\section{References}

1. EV Gromachevskaya, TP Kosulina, VG Kulnevich, VP Smolyakov (1997) Chemistry and Technology of Furan Compounds, Krasnodar 21.

2. EV Gromachevskaya, TP Kosulina, GD Krapivin, VG Kulnevich (1993) Reaction of o-aminophenyldiphenylcarbinol with unsaturated aldehydes, Chemistry of Heterocyclic Compounds 29: 1109-1110.

3. EV Gromachevskaya, VG Kulnevich, TP Kosulina, VS Pustovarov (1988), 4H-3,1-benzoxazines. 2.Synthesis of 2,4-substituted 1,2-dihydro-4H-3,1-benzoxazines, Chemistry of Heterocyclic Compounds 24: 692-697.

4. TP Kosulina, EV Gromachevskaya, VG Kulnevich (1993) Reaction of o-aminophenyldiphenylmethanol with $\alpha$-acetylenic ketone, Chemistry of Heterocyclic Compounds 29: 1232-1233.

5. F Kienzle (1983) A facile synthesis of 1,4-dihydro-1-alkyl-2H-3,1-benzoxazines and related compounds, Tetrahedron Letters 24(21): 22132216.

6. W Nijhuis, W Verboom, S Harkema, DN Reinhoudt (1989) Synthesis of 3,1-benzoxazines and 3,1-benzothiazines, Recueil des Travaux Chimiques des Pays-Bas 108: 147.

7. RS Tiwari A Uperti, RK Satsangi (1981) Synthesis of 2-Hippuryl-3-ArylQuinazolinones, Journal of the Chemical Society of Pakistan 3: 215.

8. EP Papadopoulos, CD Torres (1982) Convenient preparation of N-substituted 2-amino 4H-3, 1-benzoxazin-4-one and 3-substituted 2, 4(1H, 3H) quinazoinediones, Heterocyclic chemistry 19(2): 269-272.

9. U Rose (1991) 2-Aryl-substituted 4H-3,1-benzoxazin-4-ones as novel active substances for the cardiovascular system, Journal of Heterocyclic Chemistry 28(8): 2005-2012.

\section{ISSN: 2574-1241}

DOI: $10.26717 /$ BJSTR.2020.29.004815

Mohammad S Al-Ajely. Biomed J Sci \& Tech Res

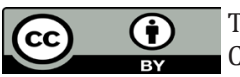

This work is licensed under Creative Commons Attribution 4.0 License

Submission Link: https://biomedres.us/submit-manuscript.php
10. H Wamhoff, S Herrmann, S Stoelben, M Nieger (1993) A new, general approach for the synthesis of heteroannulated 3,1-oxazin-4-ones, Tetrahedron 49(3): 581-594.

11. M O Osman Habib, M Hussein Hassan, B Evelin B Moawad, E-LMekabaty Ahmedl (2012) Synthetic Approaches and Biological Evaluation of Some New Sulfonate Ester-Containing Imidazolone Derivatives American Journal of Organic Chemistry 2(4): 79-86.

12. Cheng-Xi Zhang, Yu-Yuan Deng, Yi-Yang Zhang, Po Yang, Yi Gu (2015) Study on products and reaction paths for synthesis of 3,4-dihydro-2H-3-phenyl-1,3-benzoxazine from phenol, aniline and formaldehyde Chinese. Chemical Letters 26(3): 348-352.

13.ZA Sallal (2014) Synthesis and characterization of new Oxazine, Thiazine and Pyrazol derived from chalcones, Baghdad Science Journal 11(2): 477-485.

14. G Chaitra, RM Rohini (2018) Synthesis of 1,3-Oxazine derivative from Chalcone and Screening for their Anti-Oxidant and Anti-Inflammatory activity. International Research Journal of Pharmaceutical and Biosciences 4(6): 20.

15. Wu Youcan Zhang, Zhiping Yin, Hai Wang, Xiao-Feng (2019) Pd/C-Catalyzed Carbonylative Synthesis of 2. Aminobenzoxazinones from 2-Iodoaryl Azides and Amines, Organic Letters pp. A-E.

16. AM Noori (2019) Synthesis of some New Oxazin Compounds and the study of their reactions, MSc Thesis, Mosul university ,Mosul-Iraq.

17. Nadeem Siddiquia, Ruhi Alia, M Shamsher Alama, Waquar Ahsana (2010) Pharmacological Profile of Benzoxazines: A Short Review J. Chem. Pharm. Res 2(4): 309-316.

18. Zilong Tang, Zhonghua Zhu, Zanwen Xia, Hanwen Liu, Jinwen Chen, et al. (2012) Synthesis and Fungicidal Activity of Novel 2,3-Disubstituted-1,3-benzoxazines, Molecules 17(7): 8174-8185.

19. D Patronea, F Nicholas, P Batesa, J Patronea, D Pelza (2016) Identification and Optimization of Anthranilic Acid-Based Inhibitors of Replication Protein A, Chem Med Chem 11(8): 893-899.

20. JC de Wouter Bruijna, A Jos Hagemanb, Carla Araya-Cloutiera, Harry Gruppena, Jean-Paul Vinckena (2018) QSAR of 1,4-benzoxazin-3-one antimicrobials and their drug design perspectives, Bioorganic \& Medicinal Chemistry 26(23-24): 6105-6114.

21. MA Abd-Elhakeem, AM Elsayed (2013) Synthesis and antimicrobial activity of some new 2,3-disubstituted quinazoline-4(3H)-ones derivatives, Journal of Chemical and Pharmaceutical Research 5(5): 275-279.

22. Amol H Kategaonkar, Swapnil S. Sonar, Rajkumar U (2010) An Efficient Synthesis of 3,4-Dihydro-3-substituted-2H-naphtho[2,1-e] [1,3] oxazineDerivatives Catalyzed by Zirconyl (IV) Chloride and Evaluationof its Biological Activities, Bull. Korean Chem. Soc 31(6): 1657-1660.

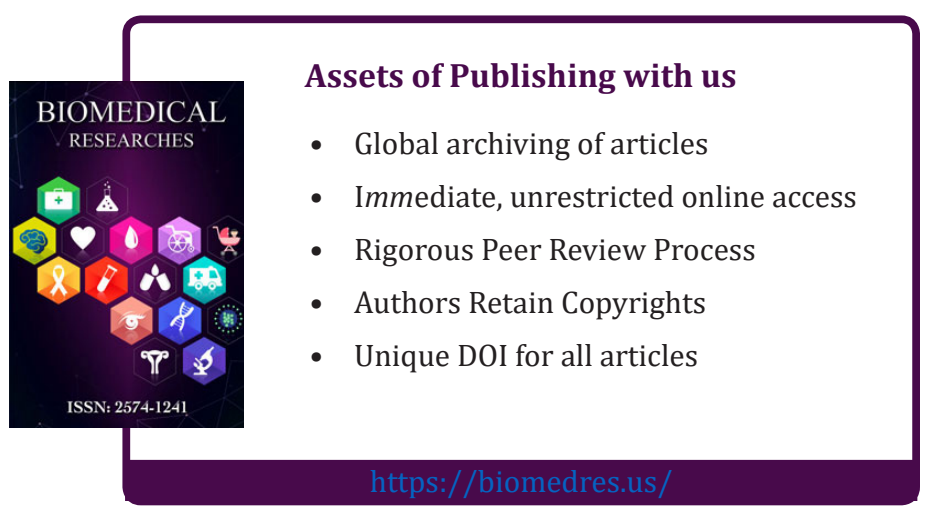

